\title{
Investigation of Misconceptions and Errors about Division Operation in Fractions
}

\author{
Devrim Üzel \\ Faculty of Education, Balıkesir University, Turkey
}

Copyright $(2018$ by authors, all rights reserved. Authors agree that this article remains permanently open access under the terms of the Creative Commons Attribution License 4.0 International License

\begin{abstract}
This study reports errors and misconceptions about division operation in fractions made by eighth-grade students. To investigate these errors and misconceptions, the study examined students' understanding of division operation in fractions using a questionnaire and expectation table. Students' misconceptions were determined for each question and compared with the expectation table. Common misconceptions of this research are; misunderstanding of word problems, incorrectly generalization of learned rules for fractions, considering numerator and denominator as integer numbers, not conceptually learning of division operation in fractions, associating division with addition, subtraction and multiplication operations. Students made same misconceptions with the expectation table.
\end{abstract}

Keywords Procedural and Conceptual Understanding, Misconceptions and Errors, Division Operation in Fractions, Eighth-grade Students

\section{Introduction}

Studies in both our country and other countries of the world have showed that students have some wrong thinking about the concepts before and after the school. Contrary to the general acceptance, giving a different meaning to a concept, misconceptions arise [1]. Misconception is defined as conceptual barriers which are an obstacle to learning. The student has misleading ideas or misapplies concepts or algorithms. Mistake is considered as computational error due to carelessness. In other words, student understands an algorithm but there is a computational error due to carelessness. Misconceptions arise frequently because student is an active participant in construction of his/her own mathematical knowledge via reception and interaction of new ideas within students' extant ideas. Unless a misconception is identified and ameliorated there is the risk of cognitive conflict and/or further misconception. In this context, misconceptions are important factors in the learning process. Difficulties encountered in learning mathematics begin with arithmetic and geometry and then increase with first input of algebra. After teaching the natural numbers in elementary schools, especially learning and teaching difficulties are rapidly increasing with the teaching of fractions. Students learn addition, subtraction, multiplication and division operations in fractions but in later years they forget how the processes were made. Students are memorizing formulas rather than understanding and they are considering numerator and denominator as two integer numbers [2]. Multiplication and division operations in fractions are especially difficult for students thus, misconceptions arise. Students develop ideas such as "Multiplication enlarges; division reduces" from multiplication and division operations in natural numbers. This idea prevents understanding multiplication and division operations in fractions. For this reason, the meaning of multiplication and division in fractions must be created by using division in natural numbers. Appropriate word problems and models should be used for this purpose. Students should develop meaning and rules of operations while they are solving these problems by using the models. Rather than the "Invert and multiply" rule, the common denominator algorithm should be utilized. The Common Denominator algorithm helps interpretation of the division of two fraction and representation [3].

Procedural and conceptual understandings are both important in our mathematics curriculum but especially concepts and their properties in focus. Multiplication and division concepts in fractions are given for the first time in the sixth-grade elementary mathematics curriculum. In the seventh-grade these concepts are given in rational numbers but not covered by eighth-grade elementary mathematics curriculum. Studies related to the concepts that have gained considerable importance in recent years. Another noteworthy point in studies is that if student's misconceptions have not been solved in time, students can carry this misconception during the life of the education. In this context, the purpose of this research was to investigate which misconceptions and errors about division operation 
in fractions were made by eighth-grade students.

\section{Method}

\subsection{Sample Group}

This study was conducted at two elementary schools in the center of Balıkesir city. Schools were selected randomly. 84 eighth-grade students from both schools participated in this study in academic year of 2017-2018.

\subsection{Data Collection Tools}

To investigate students' errors and misconceptions, the study examined their understanding of division operation in fractions using a questionnaire and expectation table consisting of expected misconceptions. Questionnaire consisting of eight questions was prepared for this research. The first 5 questions were evaluating the skills of; $i$. understanding of concepts of mixed numbers and improper fractions, ii. dividing into equal parts of a whole, iii. using visual models, $i v$. operations of addition, subtraction, multiplication and division, $v$. expressing the remainder as a fraction and vi. giving a realistic solution. The sixth question as about knowledge and skill of addition, subtraction, multiplication and division in fractions and using fraction bar as required. The seventh and the last questions were about writing word problems modeled by symbolic division operations. Word problems were expected to relevant to real life.

In the preparation of expected table, misconceptions have been identified previously in the literature were taken into consideration $[2,4,5,6,7,8,9,10,11,12,13,14,15$, $16,17,18,19]$.

\subsection{Data Analysis}

Students' solutions were taken by questionnaire and descriptively analyzed. Misconceptions and errors were determined. Existing misconceptions were compared with the expectation table in Table 1.

Table 1. Expectation Table

\begin{tabular}{|c|c|}
\hline \multicolumn{2}{|r|}{ Literature } \\
\hline $\begin{array}{l}\text { 1.Misunderstanding of fractions } \\
\text { The misunderstanding of fraction bar } \\
\text { Considering numerator and denominator as integer } \\
\text { numbers } \\
\text { Not visualizing the given fractions } \\
\text { Not considering fractions as part-whole relationship. } \\
\text { Ignoring amount indicated by fractions } \\
\text { The misunderstanding of unit } \\
\text { Different Interpretations for fractions } \\
\text { Part-Whole } \\
\text { Quotient } \\
\text { Ratio } \\
\text { Measure } \\
\text { Operator }\end{array}$ & $\begin{array}{l}\text { 2.Not conceptualization of division operation in fractions } \\
\text { Associating division with addition } \\
\text { Associating division with subtraction } \\
\text { Consider division as division of neutral numbers } \\
\text { Changing roles of the divisor and dividend } \\
\text { Divisor or dividend must be an integer number } \\
\text { Dividend is always bigger than divisor } \\
\text { Result must be bigger than } 1 \\
\text { Dividend must be bigger than divisor } \\
\text { Results must be integer number } \\
\text { Inability to give a realistic result } \\
\text { Writing a word problem using fractions } \\
\text { Inability to make the appropriate expressions to everyday life in word problems } \\
\text { Misunderstanding of remainder } \\
\text { Inability to express remainder as a fraction } \\
\text { Problems on generalization of rules } \\
\text { Misapplication of "Invert and multiply" rule } \\
\text { Misapplication of "Common denominator" rule }\end{array}$ \\
\hline \multicolumn{2}{|r|}{ Cultural differences } \\
\hline \multicolumn{2}{|c|}{ In English $\frac{3}{4}$ is read as "three-fourth", In Turkish $\frac{3}{4}$ is given with the equality of $3: 4$ thus $\frac{3}{4}$ is read as " 3 divide by 4 " } \\
\hline
\end{tabular}




\section{Findings}

Data were analyzed by using expectation table. 62 students solved the first and second question by applying the "invert and multiply" rule. 9 students associated division with addition and 11 students associated division with subtraction. 2 students left the question unanswered. These findings were parallel to expectation table. Multiplication and division operations were not conceptualized, misusage of the "invert and multiply" and "common denominator" rules, therefore generalizing the rules incorrectly, misunderstanding of fraction bar were found.

The fourth question has three sub-questions. 17 students solved the problem without operations, 6 students gave realistic solutions and 3 students left the question unanswered. The first sub question's result was found as $\frac{7}{3}$ (solution: $\frac{7}{8}: \frac{3}{8}=\frac{7}{8} \cdot \frac{8}{3}=\frac{7}{3}$ ) or $2 \frac{1}{3}$ by 23 students. This result was not realistic. Realistic result was 3 and 35 students solved accurately. The second sub question's realistic result was 2 and 58 students solved this question with dividing 7 by 3 , quotient was given as a result or mixed number' $s$ integer part was given as a result. The third question's result was found as $\frac{1}{8}$ (solution: $\frac{7}{8}-\frac{6}{8}=\frac{1}{8}$ ) by 14 students who solved the second sub question accurately. Nevertheless $\frac{1}{8}$ of pizza rests, ideal result was $\frac{1}{3}$ (solution: $\frac{1}{8}: \frac{3}{8}=\frac{1}{3}$ ) and this result was found by 38 students. In the fourth question, students were expected to solve by visualizing fractions. But only one student made visualization. This statement can be explained with
"Misunderstanding of fractions" in table 2. Fractions are modeled with shapes in mathematics courses since primary school. Therefore this finding was so interesting.

In the fifth question 40 students found $\frac{103}{18}$ as result, realistic solution was made by 8 students, 4 students solved accurately without operations and 15 students left the question unanswered. $\frac{103}{18}$ response showed that "invert and multiply" rule was effectively learned and applied. Percentage of giving realistic result to the fifth question increased. Students who gave realistic result to this question, found the result of $\frac{22}{3}$ to the third question. The fourth and the fifth questions required same solutions but a few students gave realistic results to the both questions. In this context students cannot make generalization for these questions. Only one student made that solution: $3.6=18$, so package was carried by 6 flying.

The sixth question has three sub questions ( $2: \frac{3}{4}=$ ?, $2 \frac{1}{4}: \frac{3}{4}=?$ and $\left.\frac{\frac{2}{4}}{\frac{3}{4}}=?\right) .72$ students solved all of the sub questions accurately, 3 students gave the result without solving and only one student made no solution to them. The most accurately answered question was the sixth. Operational learning was effective on applying of "invert and multiply" rule. Students were more successful at solving problems given in a symbolic way. Students, who gave the accurate result without solving, could make computations mentally or clear the solutions after finding the result.

Table 2. Misconceptions And Errors Related To The First Question

\begin{tabular}{|c|c|c|c|}
\hline Students' solutions & Misconceptions and errors & $\mathrm{f}$ & $\%$ \\
\hline 1. $\frac{9}{4}+\frac{3}{4}=\frac{12}{4}=3$ & $\begin{array}{l}\text { - } \\
\text { - } \\
\text { Assot conceptualizating division with addition }\end{array}$ & 5 & 6 \\
\hline 2. $2 \frac{1}{4}+\frac{3}{4}=2 \frac{4}{8}$ & $\begin{array}{l}\text { - } \quad \text { Associating division with addition } \\
\text { - } \quad \text { Misunderstanding of addition in fractions } \\
\text { Numerator and denominator are considered as integer numbers }\end{array}$ & 4 & 5 \\
\hline 3. $\frac{9}{4}-\frac{3}{4}=\frac{6}{4} \quad \frac{6}{4}: \frac{3}{4}=\frac{2}{4}$ & $\begin{array}{ll}\text { - } & \text { Not conceptualization of division operation in fractions } \\
\text { - } & \text { Associating division with subtraction } \\
\text { - } & \text { Misapplication of "Common denominator" rule } \\
& \text { Numerators are considered as integer numbers }\end{array}$ & 7 & 8 \\
\hline $\begin{array}{l}\frac{9}{4}-\frac{3}{4}=\frac{6}{4} \\
\frac{6}{4}=2\end{array}$ & $\begin{array}{l}\text { - } \quad \text { Not conceptualization of division operation in fractions } \\
\text { - } \quad \text { Associating division with subtraction } \\
\text { Misapplication of "Common denominator" rule Error_ }\end{array}$ & 4 & 5 \\
\hline 5. $\frac{9}{4}: \frac{3}{4}=\frac{3}{4}=3$ & $\begin{array}{l}\text { - } \quad \text { Not conceptualization of division operation in fractions } \\
\text { - } \quad \text { Misapplication of "Common denominator" rule_ } \\
\text { Changing improper fraction to integer number }\end{array}$ & 37 & 44 \\
\hline 6. $\frac{9}{4} \times \frac{4}{9}=2$ & $\begin{array}{ll}\cdot & \text { Error } \\
\text { - } & (9: 3=2)\end{array}$ & 14 & 17 \\
\hline 7. $2 \frac{1}{4} \times \frac{4^{\prime}}{3}=2 \frac{1}{3}=4$ & $\begin{array}{l}\text { - } \quad \text { Not conceptualization of multiplication operation in fractions } \\
\text { - } \quad \text { Misapplication of "Invert and multiply" rule } \\
\text { - Changing mixed number to integer number }\end{array}$ & 11 & 13 \\
\hline
\end{tabular}


The last two questions were given in symbolic and students expected to write word problems appropriate to symbolic versions. 12 students wrote word problems accurately to the seventh question, 7 students wrote word problems accurately to the eighth question.

Only 3 students made the appropriate expressions to everyday life in word problems, therefore one of them whose responses were given for seventh question is " $\frac{3}{4}$ of my pizza has left in the dinner. I want to eat rest of the pizza in two days. How much pizza can I eat per day?" and for the eighth question is, "A square has a side with the length of $\frac{2}{7} \mathrm{~cm}$. The sides will be surrounded by a wire with the length of $1 \frac{3}{5} \mathrm{~cm}$. According to this, how many sides will be covered by this wire?"

Table 3. Misconceptions And Errors Related To The Second Question

\begin{tabular}{|c|c|c|c|}
\hline Students' solutions & Misconceptions and errors & f & $\%$ \\
\hline $15: 1 \frac{2}{3}=15.1 \frac{3}{2}=\frac{45}{2}$ & $\begin{array}{l}\text { - } \quad \text { Misapplication of "Invert and multiply" rule } \\
\text { - } \quad \text { Misunderstanding of mixed numbers } \\
\text { Not conceptualization of multiplication } \\
\text { operation in fractions }\end{array}$ & 25 & 30 \\
\hline $15: \frac{5}{3}=15 \cdot \frac{5}{3}=\frac{1}{15} \cdot \frac{5}{3}=\frac{5}{45}$ & $\begin{array}{l}\text { - } \quad \text { Incorrect sembolizations } \\
\text { - Misapplication of "Invert and multiply" rule }\end{array}$ & 17 & 20 \\
\hline $\begin{array}{c}1 \frac{2}{3}+15=1 \frac{17}{3} \quad 1 \frac{2}{3}+5 \frac{5}{10}=6 \frac{7}{13} \\
1 \frac{2}{3}+\frac{15}{3}=1 \frac{17}{3}\end{array}$ & $\begin{array}{l}\text { - } \\
\text { - } \quad \text { Numerator is considered as integer numbers } \\
\text { - Misapplication of "Common denominator" } \\
\text { rule }\end{array}$ & 13 & 15 \\
\hline $\begin{array}{c}15: \frac{5}{3}=\frac{45}{3}: \frac{5}{3}=\frac{15}{3}=5 \\
15 \times \frac{5}{3}=25\end{array}$ & $\begin{array}{ll}\text { - } & \text { Misapplication of "Common denominator" } \\
\text { - } & \text { Eule } \\
\text { - } & (45: 5=15) \\
\text { - } & \text { Associating division with multiplication } \\
\text { - } & \text { Error } \\
\text { - } & (15 \times 5=75)\end{array}$ & 11 & 10 \\
\hline$\frac{1 \frac{2}{3}}{\frac{15}{1}}=\frac{5}{3} \times \frac{15}{1}=\frac{75}{3}=25$ & $\begin{array}{l}\text { - } \quad \text { Changing roles of the divisor and dividend } \\
\text { - } \quad \text { Associating division with multiplication }\end{array}$ & 8 & 10 \\
\hline
\end{tabular}

Table 4. Misconceptions and Errors Related To the Fifth Question

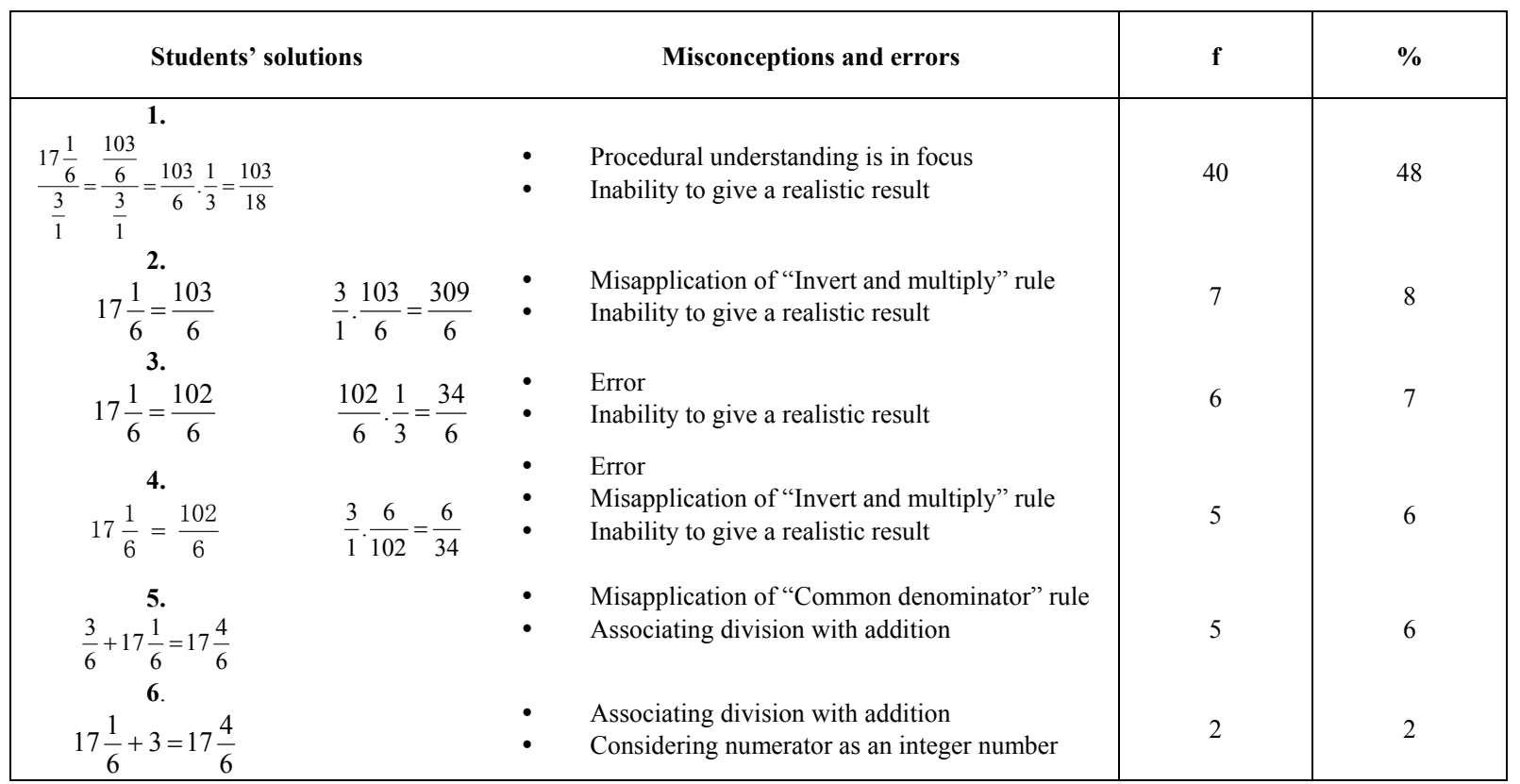


Table 5. Misconceptions And Errors Related To The Eighth Question

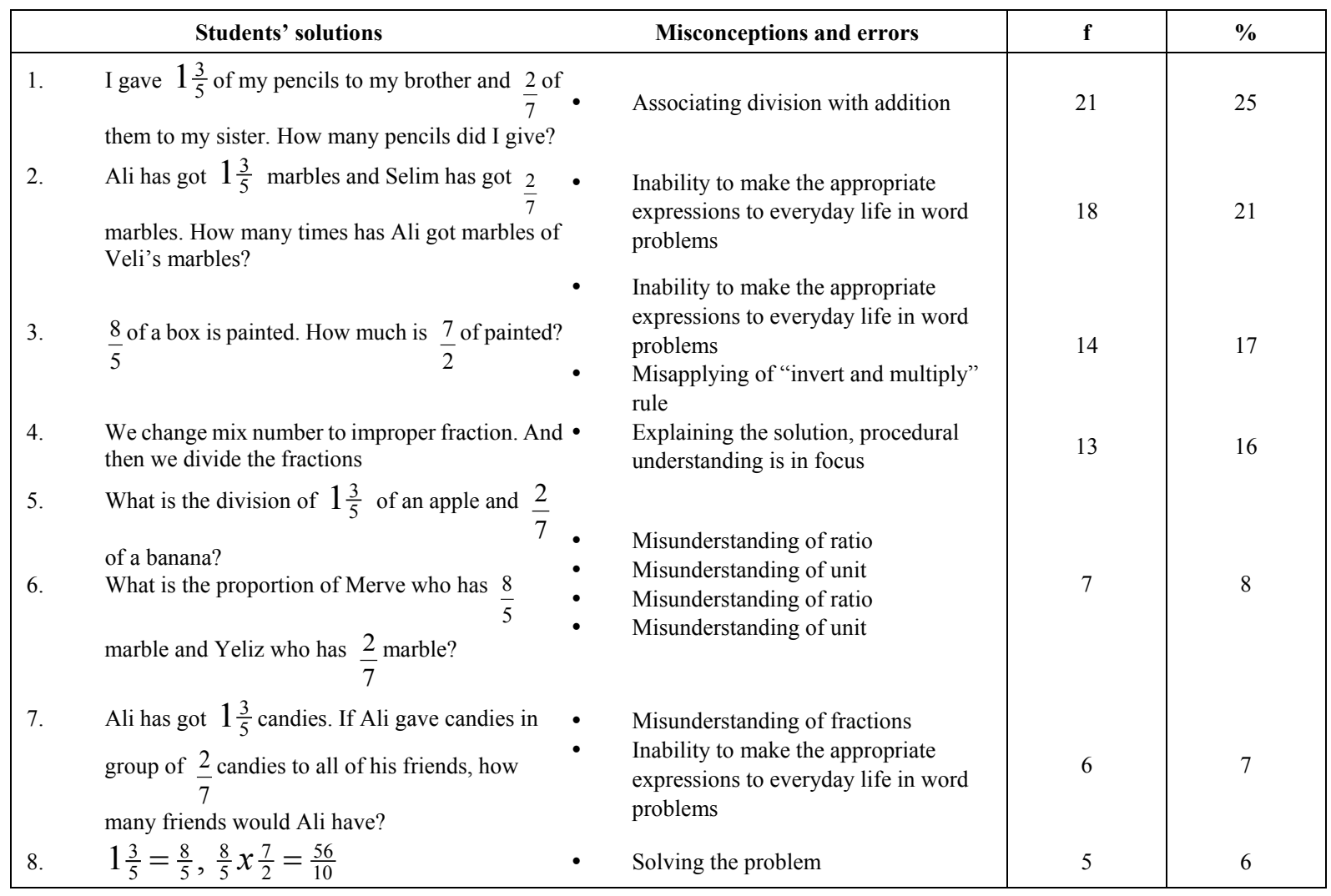

\section{Discussion}

Misconceptions parallel to the statements in the expectation table have been identified. Common misconceptions of this research are; misunderstanding of word problems, incorrectly generalization of learned rules for fractions, considering numerator and denominator as integer numbers, not conceptually learning of division operation in fractions, associating division with addition, subtraction and multiplication operations. It was found that understanding of concept of fractions have an important role in encountering difficulty with division operation in fractions. The misconception of misunderstanding of fractions was occurred in findings and this was explained with fractions' multifaceted construct [12, 13, 14].

Associating division with addition, subtraction and multiplication operations could be explained with the result that students who are accustomed to additive reasoning may have difficulties in multiplicative reasoning. Behr \& Post[20] and Lamon[14] views the importance of being aware of the need to shift from additive to multiplicative thinking. In this study, students carried "the common denominator" rule to multiplication and division operations in fractions. As a result, students have memorized the rules and made incorrect generalization. This situation was realized in "common denominator" and "invert and multiply" rules. Division operation is taught with the "2 divided by 3 "in Turkey, therefore students are usually using "invert and multiply" rule instead of taking account of part-whole relationship. This result was in line with the study of Toluk[10]. In the solution of first five problems, using the rule of "invert and multiply" was sufficient only in first, second and sixth questions. In addition, students needed to make realistic (according to daily life) interpretations in third, fourth and fifth questions and have the ability to express remainder as a fraction but many of the students did not succeed. Students' inabilities of reasoning remainder in division operation in fractions were also found in many researches [21, 22, 23, 24, 25]. A remarkable exception in study was that none of the students made drawings or used concrete models to understand verbal problems. Cramer and Henry [26] noted that using concrete models over extended periods of time helps children to develop mental images for fractions. This understanding then leads to students being able to perform fraction operations in meaningful ways. Students should work with physical models, pictures, realistic contexts, and verbal descriptions [27].

Especially last two questions were explored in detail. The students were asked to write word problems that can be resolved with given mathematical operations. Students have written problems based on already familiar, common questions asked in mathematics text books. The most misconceptions were digitizing of fractions and misapplying of "invert and multiply" rule. $1 \frac{3}{5}$ ball cannot be; instead of this, " $1 \frac{3}{5}$ of my balls" expression should be 
used. The concept of ratio was not conceptualized, proportion of an amount of bananas and apples, and proportion of individuals. This result was in line with the Eighth-Grade NAEP Results. There was found that a significant change, the percentage of students who were able to write a word problem using fractions, was a decrease in Eighth-Grade NAEP Results [28]. "Writing a word problem using fractions" misconception was occurred and although word problems were given in the first 5 questions, only 3 students had ability to make the appropriate expressions to everyday life in word problems. Kerslake [29] warns that learning only the part-whole model can result in serious limitations on children's understanding of fractions.

In line with the findings from the research; students could interpret mathematics in realistic and everyday life, they could be aware of what they learned; training activities lead students to think must be implemented. Learning areas of concepts and relationships are in the focus of curriculum. Conceptual approach provides more time to build the conceptual foundations of math-related information, so this approach is required to establish relations between conceptual and operational knowledge and skills. By taking this way of teaching, students' misconceptions about division in fractions is expected to be minimizing. The research highlighted the importance of using misconceptions as an educational tool.

\section{REFERENCES}

[1] Akkaya, R. ve Durmuş, S., (2006). İlköğretim 6-8. Sınıf öğrencilerinin Cebir Öğrenme Alanındaki Kavram Yanılgıları, Hacettepe Üniversity. Journal of Education Faculty,31, 1-12.

[2] Soylu, Y. ve Soylu, C. (2005). İlköğretim Beşinci Sınıf Öğrencilerinin Kesirler Konusundaki Öğrenme Güçlükleri: Kesirlerde Siralama, Toplama, Çıkarma, Çarpma Ve Kesirlerle İlgili Problemler, Erzincan Educational Faculty Journal, 7,2, Online:

http://www.erzincan.edu.tr/birimler/egitim/userfiles/eefder gi/7_2/7_2_8_soylular.pdf.

[3] Ministry of National Education (2007). Online: http://ttkb.meb.gov.tr/program.aspx?tur=ilkogretim\&lisetu $\mathrm{r}=\&$ sira $=$ derse \&ders $=$ Matematik.

[4] Kieren, T. E. (1980). Recent research on number learning (pp. 125-149): ERIC Clearinghouse for Science, Mathematics, and Environmental Education.

[5] Ohlsson, S. (1988). Mathematical meaning and applicational meaning in the semantics of fractions and related concepts. In J. A. Hiebert \& M. J. Behr (Eds.), Number concepts and operations in the middle grades (pp. 53-92). Hillsdale, NJ: Lawrence Erlbaum Associates.

[6] Moseley, B. J. \& Okamoto, Y. \& Ihsida, J.( 2007). Comparıng US and Japanese Elementary School Teachers' Facility For Linking Rational Number Representations. International Journal of Science and Mathematics
Education (2007) 5: 165-185.

[7] Orhun, N.(2007). Kesir İșlemlerinde Formal Aritmetik ve Görselleştirme Arasındaki Bilişsel Boşluk.İnönü Üniversitesi Eğitim Fakültesi Dergisi, 8(14), 99-111.

[8] Gürbüz, R. \& Birgin, O. (2008). Farklı Öğrenim Seviyesindeki Öğrencilerin Rasyonel Sayıların Farklı Gösterim Şekilleriyle İşlem Yapma Becerilerinin Karşılaştırılması.Pamukkale Üniversiy. Journal of Education Faculty(1) 23, 85-94.

[9] Prediger, S.(2008). The Relevance of Didactic Categories for Analysing Obstacles in Conceptual Change: Revisiting the Case of Multiplication of Fractions. Learning and Instruction 18, 3-17.

[10] Toluk, Z.(2002). İlkokul Öğrencilerinin Bölme İşlemi ve Rasyonel Sayıları İlişkilendirme Süreçleri. Boğaziçi Üniversitesi Eğitim Dergisi, 19(2).

[11] Kılcan, A. S. (2006). İlköğretim Matematik Öğretmenlerinin Kesirlerde Bölmeye İlişkin Kavramsal Bilgi Düzeyleri, Abant İzzet Baysal University, Institute of Social Sciences. Unpublished master thesis.

[12] Behr, M., Harel, G., Post, T., \& Lesh, R. (1992). Rational number, ratio and proportion. In D. A. Grows (Ed.) Handbook on research on mathematics teaching and learning (pp. 296-333). New York: Macmillan.

[13] Kieren, T. E. (1993). Rational and fractional numbers: From quotient fields to recursive understanding. In T. P. Carpenter, E. Fennema, \& T. A. Romberg (Eds.), Rational numbers: An integration of research (pp. 49-84). New Jersey: Erlbaum.Kilpatrick, J., Swafford, J., \& Findell, B. (2001). Adding it up: Helping children learn mathematics. Washington, D. C.: National Academy Press.

[14] Lamon, S. (1999). Teaching fractions and ratios for understanding: Essential content knowledge and instructional strategies for teachers. Mahwah, NJ: Lawrence Erlbaum Associates.

[15] Powell, C. A., \& Hunting, R. P. (2003). Fractions in the early-years curriculum: More needed, not less. Teaching Children Mathematics, 10(1), 6-7.

[16] Post, T., Behr, M. J., \& Lesh, R. A. (1982). Interpretations of rational number concepts. In L. Silvey (Ed.), Mathematics for the middle grades (5-9) (pp. 59-72). Reston, VA: National Council of Teachers of Mathematics.

[17] Lamon, S. (1993). Ratio and proportion: Children's cognitive and metacognitive processes. In T. P. Carpenter, E. Fennema \& T. A. Romberg (Eds.), Rational numbers: An integration of research. Hillsdale, NJ: Lawrence Erlbaum Associates.

[18] Pothier, Y., \& Sawada, D. (1990). Partitioning: An approach to fractions. Arithmetic Teacher, 38(4), 12-16.

[19] Kieren, T. E. (1992). Rational and fractional numbers as mathematical and personal knowledge: Implications for curriculum and instruction. In G. Leinhardt, R. Putnam \& R. A. Hattrup (Eds.), Analysis of arithmetic for mathematics teaching (pp. 323-371). Hillsdale, NJ: Lawrence Erlbaum Associates.

[20] Behr, M. J., \& Post, T. (1992). Teaching rational number and decimal concepts. In T. Post (Ed.), Teaching 
mathematics in grades K-8: Research-based methods (pp. 201-248). Reston, VA: National Council of Teachers of Mathematics.

[21] Silver, E. A., Mukhopadhyay, S. \& Gabriele, A. J. (1992). Referential Mappings and the Solution of Division Story Problems Involving Remainders. Focus on Learning Problems in Mathematics, 14(3), 29-39.

[22] Ca1, J. \& Silver, E. A. (1993). Solution Processes and Interpretations of Solutions inSolving a Division- WithRemainder Story Problem: Do Chinese and U. S. Students Have Similar Difficulties?. Brief Report.

[23] Silver, E. A., Shapiro, L. J.\& Deutsch, A. (1993). Sense Making and The Solution of Division Problems Involving Remainders: An Examination of Middle School Students' Solution Processes and Their Interpretations of Solutions. Journal for Research in Mathematics Education, 24(2), 117-135.

[24] Simon, M. A. (1993). Prospective Elementary Teachers' Knowledge of Division. Journal for Research in Mathematics Education, 24(3), 233-254.
[25] De Franco, T. C. \& Curcio, F. R. (1997). A Division Problem With A Remainder Embedded Across Two Contexts: Children's Solutions in Restrictive vs. Realworld Settings. Focus on Learning Problems in Mathematics, 19(2), 58-72.

[26] Cramer, K. A., \& Henry, A. (2002). Using manipulative models to build number sense for addition and fractions. In B. Litwiller (Ed.), Making sense of fractions, ratios, and proportions (pp. 41-48). Reston, VA: National Council of Teachers of Mathematics.

[27] Kilpatrick, J., Swafford, J., \& Findell, B. (2001). Adding It Up: Helping Children Learn Mathematics. Washington, DC: National Academy Press.

[28] Kastberg, S. E., \& Norton, A. I. (2007). Building a system of rational numbers. In P. Kloosterman \& F. Lester (Eds.), Results and interpretations of the 2003mathematics assessment of the National Assessment of Educational Progress (pp. 67-93). Reston, VA: National Council of Teachers of Mathematics.

[29] Kerslake, D. (1986). Fractions: Children's strategies and errors. Berkshire, England: NFER-Nelson. 